\title{
Debris flow induced by glacial lake break in southeast Tibet
}

\author{
Z. L. Cheng ${ }^{1,2}$, J. J. Liu ${ }^{1,2,3}$ \& J. K. Liu ${ }^{1,2,3}$ \\ ${ }^{1}$ Key Laboratory of Mountain Hazards and Surface Process, \\ Chinese Academy of Sciences, China \\ ${ }^{2}$ Institute of Mountain Hazards and Environment, CAS, China \\ ${ }^{3}$ Graduate University of Chinese Academy of Sciences, China
}

\begin{abstract}
Debris flow caused by flooding of a glacier-lake break can result in major disasters in southeast Tibet. Based on field investigation and data analysis, this paper discusses the influences of climate factors on lake break. It is found that the break is inclined to occur after abnormal changes in climate, particularly at the turn from cold-wet weather to hot-dry weather. Debris flows due to glaciers will be more active in future decades.

Keywords: debris flow induced by glacier-lake break, climate change, disaster, southeast Tibet.
\end{abstract}

\section{Introduction}

Debris flow induced by glacial lake break has brought about tremendous disasters to lives and properties in southeast Tibet. For example, icefalls occurred widely on June 29, 1983, August 23, 1984, and July 20, 1985, blocking the glacier and forming temporary lakes. All three lakes finally broke and the flood created great debris flows, with peak discharge up to 2950, 5245, and 8195 $\left(\mathrm{m}^{3} / \mathrm{s}\right)$, respectively. They blocked the south Sichuan-Tibet highway for 270 days, destroyed 54 bridges, $8 \mathrm{hm}^{2}$ farmland, 22 houses, and 79 trucks, amounting to a loss of 2 million dollars (Fig.1). another event is the break of the Guangxiecuo lake, where the resulting debris flow entered the upper Palongzangbu River at a discharge of $1021.4 \mathrm{~m}^{3} / \mathrm{s}$ and partially blocked the river, raising the water level up to more than $10 \mathrm{~m}$. The flow rushed down, destroying $42 \mathrm{~km}$ highway, and suspending traffic for 200 days. It also washed out 18 
bridges, destroyed 51 houses, and killed 5 persons. The total loss amounted to more than 10 million dollars [1]. Since the event this section has become more and more fragile and suffered from frequent traffic accidents [2]. Glacial lakes are mainly distributed in the rivers of Yaluzangbu, Palongzangbu, Niyang, Boqu, and Pengqu (Fig.2), and control measures have been taken since the 1980s [3-8].

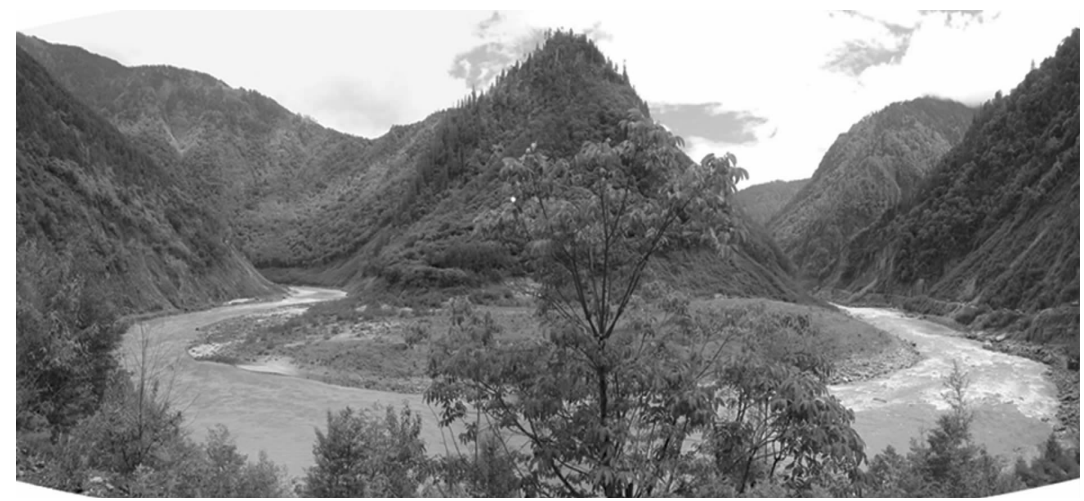

Figure 1: A debris flow fan in Peilong Gully.

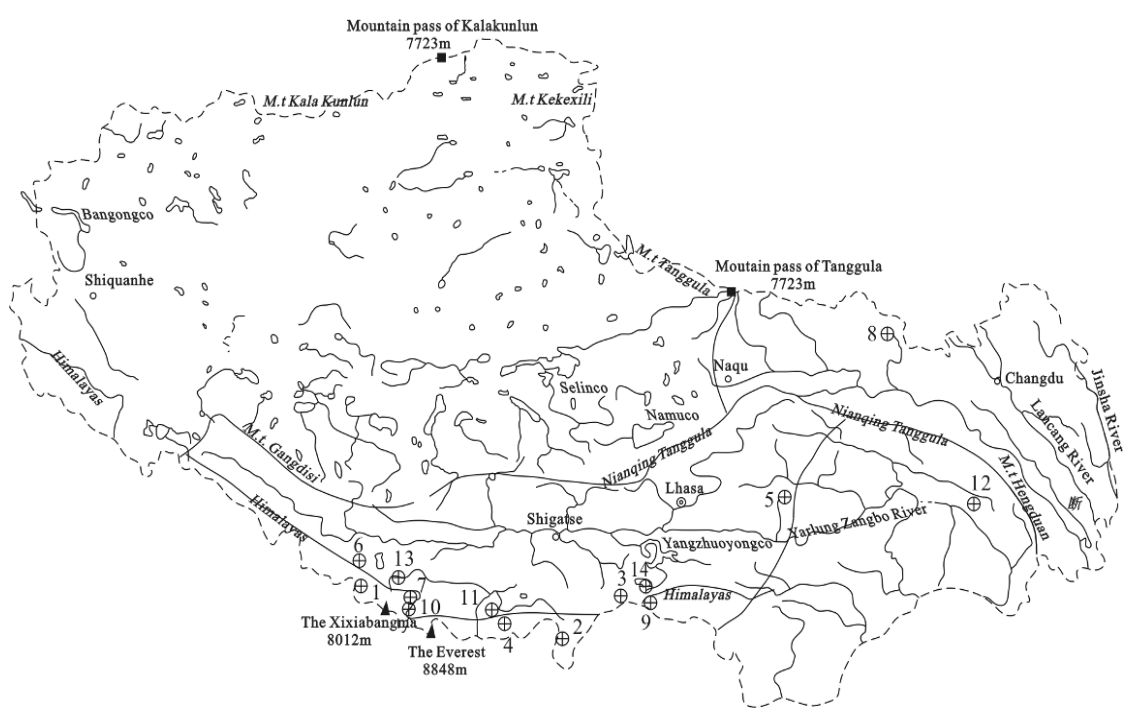

Figure 2: The distribution of debris flow induced by GLOFs in Southeast Tibet (excluding the lakes resulting from icefall), [9]: 1-Taco, 2Qiongbihemaco, 3-Sangwangco, 4-Jilaico, 5-Damenlakeco, 6-Longdaco, 7-Ayaco, 8-Bangeco, 9-Zharico, 10Cirenmaco, 11-Jingco，12-Guangxieco，13-Jialongco, 14Degaco. 
The climate is crucial to the outburst of glacial lakes. Tufnell [10] analyzed more than 50 events in the Alps, finding that over 95\% happened between July and September and were concentrated in June and August. Out of the 18 identified events in Tibet, six occurred in August and in the extreme alpine regions of the Himalayas [11]. Climate change may be the cause of outbursts throughout the world. The events in Tibet mainly happened in 1964, when the weather fluctuated greatly between cold and hot; and also in the transition from the cold-wet years of the 1960s to the hot-dry years of the 1970s and 1980s. In particular, abnormal weather may be the direct cause of lake break. It is reported that the event at Guangxiecuo was due to the persistently high temperature and extreme rainstorm.

This paper discusses the climate influence on glacial lake break, and analyses the trend of glacial lakes in southeast Tibet under global warming conditions.

\section{Climate factors}

Many factors are influential on the breaking of glacial lakes, including the size and thickness of glaciers, the area and impounded water of the lake, structure and stability of the embankment, and temperature and precipitation. Among them the last two are decisive. In the monsoon climate the summer is warm and rainy in southeast Tibet: this increases the melted water, which enters the lake and raises the water level or even brings about overflow. Heavy rainfall is also important. On the other hand, the melted water converges toward the glacial front and infiltrates into the cracks. It fabricates the substrate and fills the pores. A critical equilibrium occurs when the captured water reaches 0.9 times the original depth. Once the equilibrium breaks, i.e., the shear stress of the front goes beyond the friction between the glacier and the substrate, the front will jump and the glacier splits into pieces of icefalls pouring into the lake. Then the water rises and the wave surges and wallops the moraine dike and finally causes the lake collapse.

The 25 break events display a close relationship to the climate condition. All the events happened between May and September, particularly June and August (Table 1). Precipitation is abundant in April and July in southeast Tibet, which provides plenty of water for the break in the following months.

\section{Annual variation of climate and glacial lake break}

Climate conditions change over months and years, as does the breaking of glacier lakes.

Table 1 and fig. 4 indicate that the rate of break is two or less for the ten years before 1960, and for 1970-1980 and 1990-2000; and it is seven or less for 19601970 and 1980-1990. The present decade is another active period, seeing four events from 2000 to 2008. 
104 Monitoring, Simulation, Prevention and Remediation of Dense and Debris Flows III

Table 1: The date of debris flow due to glacier lake break in southeast Tibet $[9,11]$.

\begin{tabular}{|c|c|c|c|c|c|}
\hline Glacier lake & Watershed & Country & $\begin{array}{l}\text { Burst } \\
\text { date }\end{array}$ & Disaster forms & $\begin{array}{l}\text { The causes } \\
\text { for outburst }\end{array}$ \\
\hline Lulang lake & $\begin{array}{l}\text { Polong } \\
\text { zangbu }\end{array}$ & Bomi & 1931.6 .8 & $\begin{array}{l}\text { Dilute debris } \\
\text { flow, floods }\end{array}$ & $\begin{array}{c}\text { Icefall, } \\
\text { Glacial } \\
\text { movement }\end{array}$ \\
\hline Daruoco & Boqu & Nielamu & 1935.8 .28 & $\begin{array}{c}\text { Floods, debris } \\
\text { flow }\end{array}$ & $\begin{array}{c}\text { Glacial } \\
\text { movement }\end{array}$ \\
\hline $\begin{array}{l}\text { Qiongbihe } \\
\text { maco }\end{array}$ & Kangbuqu & Yadong & 1940.7 .10 & $\begin{array}{l}\text { Floods, debris } \\
\text { flow }\end{array}$ & Icefall \\
\hline Sangwangco & Nianchu & Kangma & 1954.7 .16 & $\begin{array}{l}\text { Dilute debris } \\
\text { flow, floods }\end{array}$ & $\begin{array}{c}\text { Glacial } \\
\text { movement }\end{array}$ \\
\hline Jilaipuco & Pengqu & Dingjie & 1964.9.21 & $\begin{array}{l}\text { Dilute debris } \\
\text { flow, floods }\end{array}$ & $\begin{array}{c}\text { Glacial } \\
\text { movement }\end{array}$ \\
\hline Longdaco & $\begin{array}{l}\text { Jilong } \\
\text { zangbu }\end{array}$ & Jilong & 1964.8 & $\begin{array}{l}\text { Floods, debris } \\
\text { flow }\end{array}$ & $\begin{array}{c}\text { Icefall, } \\
\text { Glacial } \\
\text { movement }\end{array}$ \\
\hline Damen lakeco & Niyang & $\begin{array}{l}\text { Gongbu } \\
\text { jiangda }\end{array}$ & $\begin{array}{l}1964.9 .28 \\
1968.8 .15\end{array}$ & $\begin{array}{l}\text { Floods, Dilute } \\
\text { debris flow, } \\
\text { Viscous debris } \\
\text { flow }\end{array}$ & $\begin{array}{c}\text { Icefall, } \\
\text { Glacial } \\
\text { movement }\end{array}$ \\
\hline Ayico & Pengqu & Dingri & $\begin{array}{l}1969.8 .17 \\
1970.8 .17\end{array}$ & $\begin{array}{l}\text { Floods, Dilute } \\
\text { debris flow, } \\
\text { Viscous debris } \\
\text { flow }\end{array}$ & $\begin{array}{c}\text { Glacial } \\
\text { movement }\end{array}$ \\
\hline Bangeco & Nujiang & Suo & $\begin{array}{l}1968.8 \\
1972.7\end{array}$ & $\begin{array}{l}\text { Dilute debris } \\
\text { flow, floods }\end{array}$ & $\begin{array}{c}\text { Icefall, } \\
\text { Glacial } \\
\text { movement }\end{array}$ \\
\hline Zharico & $\begin{array}{l}\text { Luozha } \\
\text { xiongqu }\end{array}$ & Luozha & 1981.6 .24 & $\begin{array}{l}\text { Floods, debris } \\
\text { flow }\end{array}$ & $\begin{array}{c}\text { Icefall, } \\
\text { Glacial } \\
\text { movement }\end{array}$ \\
\hline $\begin{array}{l}\text { Zhang } \\
\text { zangco }\end{array}$ & Boqu & Nielamu & 1964 & $\begin{array}{c}\text { Floods, debris } \\
\text { flow }\end{array}$ & $\begin{array}{c}\text { Glacial } \\
\text { movement }\end{array}$ \\
\hline $\begin{array}{l}\text { Ciren } \\
\text { maco }\end{array}$ & Boqu & Nielamu & 1981.7.11 & $\begin{array}{l}\text { Floods, debris } \\
\text { flow }\end{array}$ & $\begin{array}{l}\text { Icefall, } \\
\text { Piping }\end{array}$ \\
\hline Jingco & Pengqu & Dingjie & 1982.8 .27 & $\begin{array}{c}\text { Floods, debris } \\
\text { flow }\end{array}$ & Icefall \\
\hline $\begin{array}{c}\text { Upstream } \\
\text { Peilong }\end{array}$ & $\begin{array}{l}\text { Palong } \\
\text { zangbu }\end{array}$ & Linzhi & $\begin{array}{l}1983.7 .29 \\
1984.8 .23 \\
1985.6 .20 \\
\end{array}$ & $\begin{array}{c}\text { Floods, Viscous } \\
\text { debris flow }\end{array}$ & Icefall \\
\hline
\end{tabular}


Table 1: $\quad$ Continued.

\begin{tabular}{|c|c|c|c|c|c|}
\hline Guangxieco & $\begin{array}{l}\text { Palong } \\
\text { zangbu }\end{array}$ & Bomi & 1988.7 .14 & $\begin{array}{l}\text { Dilute debris } \\
\text { flow, floods }\end{array}$ & $\begin{array}{c}\text { Icefall, } \\
\text { Glacial } \\
\text { movement }\end{array}$ \\
\hline $\begin{array}{l}\text { Jianglong } \\
\text { lake }\end{array}$ & Boqu & Nielamu & $\begin{array}{l}2002.5 .23 \\
2002.6 .29\end{array}$ & $\begin{array}{l}\text { Viscous debris } \\
\text { flow, Dilute } \\
\text { debris flow, } \\
\text { Floods }\end{array}$ & $\begin{array}{c}\text { Icefall, } \\
\text { Glacial } \\
\text { movement }\end{array}$ \\
\hline Degaco & $\begin{array}{l}\text { Luozha } \\
\text { xiongqu }\end{array}$ & Luozha & 2002.9 .18 & $\begin{array}{l}\text { Viscous debris } \\
\text { flow, Dilute } \\
\text { debris flow, } \\
\text { Floods }\end{array}$ & $\begin{array}{c}\text { Icefall, } \\
\text { Glacial } \\
\text { movement }\end{array}$ \\
\hline $\begin{array}{c}\text { Jianmu } \\
\text { puqu }\end{array}$ & $\begin{array}{l}\text { Palong } \\
\text { zangbu }\end{array}$ & Linzhi & 2008.4 .9 & $\begin{array}{l}\text { Viscous debris } \\
\text { flow, Dilute } \\
\text { debris flow, } \\
\text { Floods }\end{array}$ & Icefall \\
\hline
\end{tabular}

Table 2: $\quad$ The monthly mean temperature at the entrance to Peilong Gully (1984m) during 1982-1985 $\left({ }^{\circ} \mathrm{C}\right)$.

\begin{tabular}{cccccccccccccc}
\hline month & 1 & 2 & 3 & 4 & 5 & 6 & 7 & 8 & 9 & 10 & 11 & 12 & annual \\
\hline 1982 & 5.0 & 6.1 & 9.2 & 13.1 & 16.4 & 18.8 & 21.1 & 21.8 & 18.4 & 13.5 & 8.2 & 5.1 & 13.1 \\
1983 & 3.1 & 4.8 & 8.9 & 11.9 & 17.0 & 19.1 & 21.4 & 21.0 & 19.0 & 14.4 & 8.2 & 4.5 & 12.8 \\
1984 & 4.7 & 8.4 & 11.1 & 13.2 & 16.5 & 19.0 & 20.6 & 20.9 & 17.9 & 15.5 & 8.0 & 6.5 & 13.6 \\
1985 & 5.2 & 7.2 & 10.9 & 13.6 & 16.8 & 19.0 & 20.1 & 22.0 & 18.3 & 13.4 & 8.6 & 5.9 & 13.4 \\
average & 4.5 & 6.6 & 10.0 & 13.0 & 16.7 & 20.0 & 20.8 & 21.9 & 18.4 & 14.2 & 8.3 & 5.5 & 13.2 \\
\hline
\end{tabular}

Table 3: $\quad$ The monthly precipitation at the entrance to Peilong Gully (1984m) during 1982-1985 (mm).

\begin{tabular}{cccccccccccccc}
$\begin{array}{c}\text { month } \\
\text { year }\end{array}$ & 1 & 2 & 3 & 4 & 5 & 6 & 7 & 8 & 9 & 10 & 11 & 12 & annual \\
\hline 1982 & 8.6 & 46.6 & 110.2 & 171.9 & 144.4 & 357.5 & 136.7 & 40.8 & 314.4 & 84.3 & 45.4 & 18.9 & 1497.7 \\
1983 & 9.4 & 61.0 & 146.3 & 127.0 & 67.0 & 192.3 & 138.0 & 63.1 & 114.9 & 144.9 & 27.5 & 8.9 & 1100.3 \\
1984 & 11.0 & 17.7 & 106.3 & 220.8 & 104.1 & 243.4 & 157.3 & 122.0 & 145.0 & 116.6 & 10.3 & 21.4 & 1257.9 \\
1985 & 21.0 & 13.5 & 188.4 & 244.5 & 109.6 & 319.9 & 182.6 & 87.8 & 181.6 & 69.4 & 16.9 & 36.8 & 1472.0 \\
average & 12.5 & 34.7 & 137.8 & 191.1 & 106.3 & 278.3 & 153.7 & 78.4 & 189.0 & 103.8 & 25.0 & 21.5 & 1332.0 \\
\hline
\end{tabular}




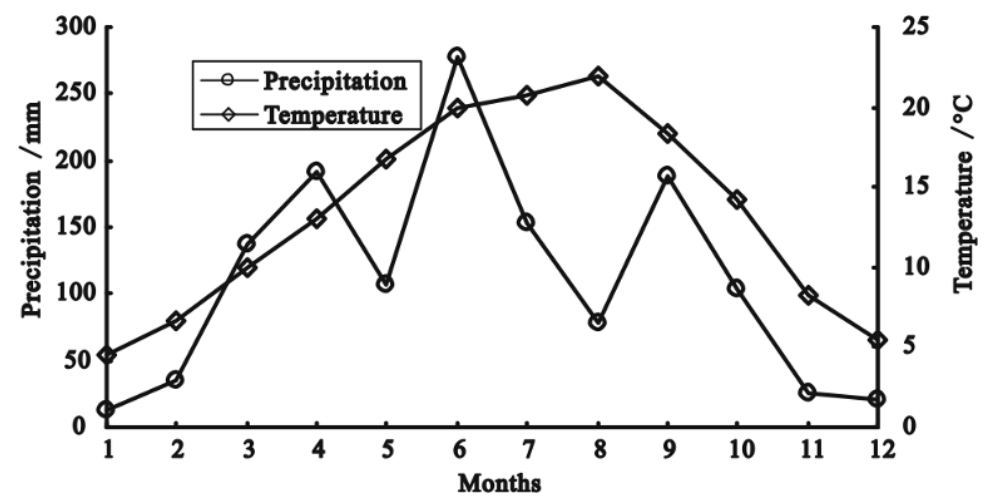

Figure 3: $\quad$ Monthly mean precipitation and temperature during 1982-1985 in the outlet to Peilong Gully, Linzhi County.

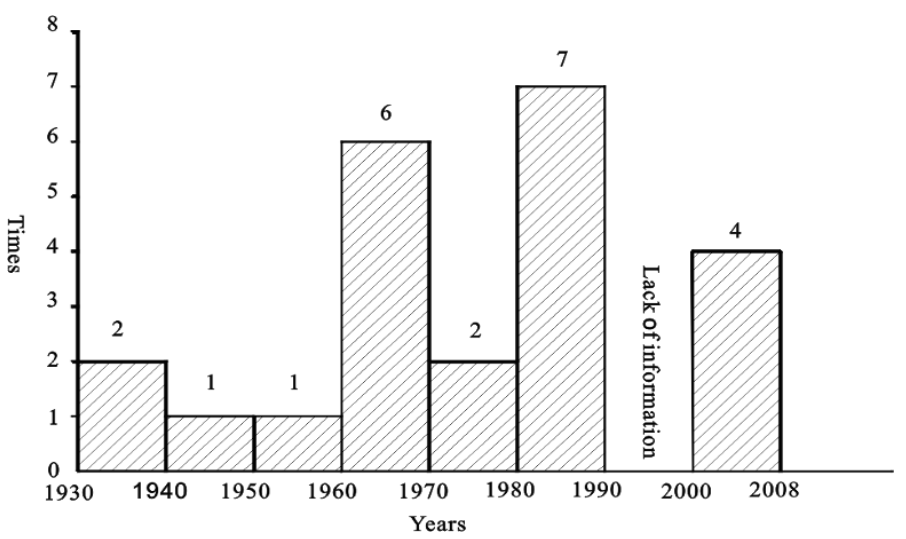

Figure 4: Annual variation of glacier lake outburst in Southeast Tibet.

\subsection{Warming and lake growing}

While cold-wet weather facilitates growth and advance the glacier, hot-wet and hot-dry weather result in melting and retreat, and therefore increase the number and size of glacier lakes [12].

The regional warming of Tibet in the last 50 years, with remarkable annual fluctuation of rainfall (Figs.8, 9), has increased both the number and size of glacial lakes. For examples, the increase is up to $11 \%$ and $47 \%$, respectively, for the number and area of glacial lakes in the Boqu River, from 1987 to 2005 (11 lakes with $17.6 \mathrm{~km}^{2}$ in area). In Pengqu, the area has increased by $13 \%$ since the $1980 \mathrm{~s}$, amounting to $47.5 \mathrm{~km}^{2}$, and in Dingjie County, the lake has grown by $0.12 \mathrm{~km}^{2}$ and the water has risen by $1 \mathrm{~m}$, with the impounded water up to 5.5 million $\mathrm{m}^{3}$.

Another example is the Palongzangbu, where many large monsoon oceanic glaciers have developed. According to Landsat TM data of 1990, 2005, and 
2006, there are 732 glacier lakes in this area, out of them 142 were created between 1970 and 2006, amounting to $10.4 \mathrm{~km}^{2}$. Figs.5-7 show three examples.

Using available data we have analyzed changes to 493 glacial lakes in the years 1970, 1990, and 2000. The results show that the lake area increased by 9.11\% during 1990 and 2000; and 215 (including 75 newly born) lakes have grown since 1970. There are 99 lakes whose area has doubled or more. There are also 278 lakes that have shrunk or even disappeared (31). Some lakes have

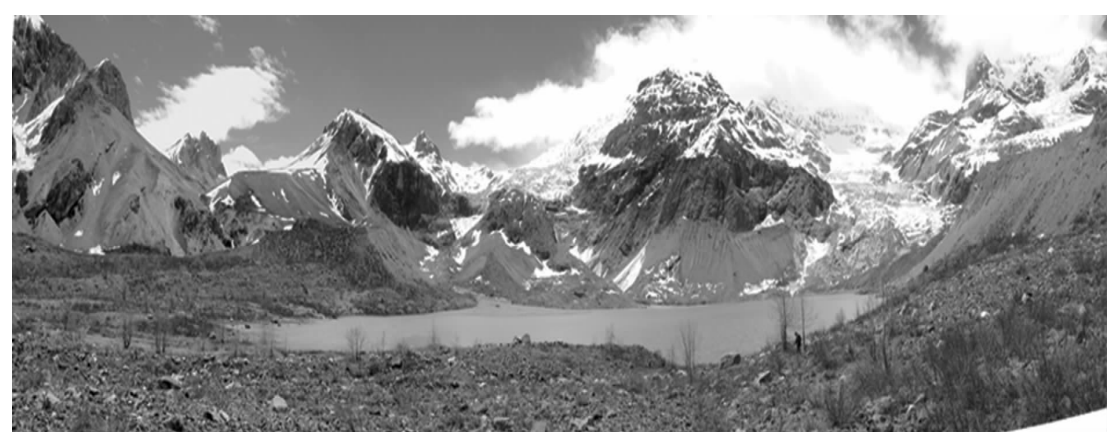

Figure 5: Duoyico, taken by Xie Hong.

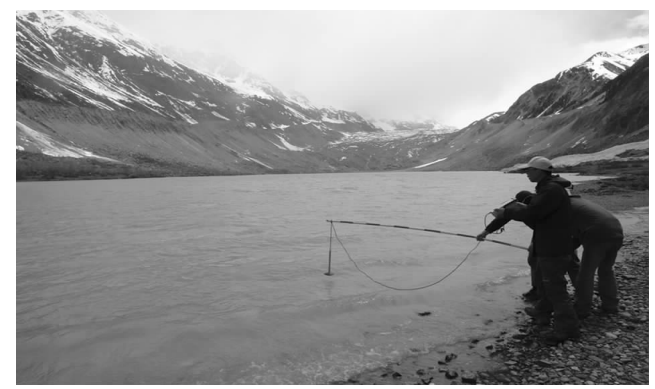

Figure 6: Kangzhaico, taken by Xie Hong.

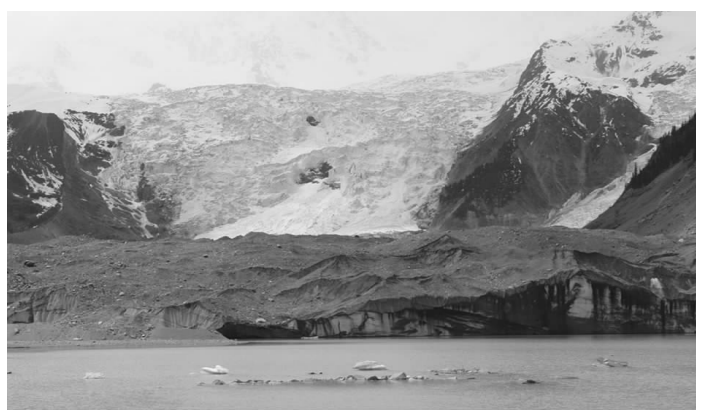

Figure 7: Guangxieco, taken by Xie Hong. 
increased remarkably in recent years, including Dankalongba in the south of Bomi, 10km from the Palongzangbu, which were measured at $206178 \mathrm{~m}^{2}$ and $214222 \mathrm{~m}^{2}$, respectively, in 1987 and 1999, while they were absent in 1970s. Guangxieco, with only $0.08 \mathrm{~km}^{2}$ left after the break in 1988 , is $0.20 \mathrm{~km}^{2}$ at present. There are other lakes with an area increased by $0.2 \mathrm{~km}^{2}$.

\subsection{Abnormal climate and lake break}

In the early 1960s glaciers in Tibet grew widely because of the cold-wet weather. However, they are prone to break as the weather becomes hot and dry. Climate abnormality is particularly related to the lake failure. Abrupt changes in climate occurred in the early 1960s and early 1980s (Table 4). A comparison between Table 1 and Table 4 indicates that lake failure occurred mainly in the abnormal years, such as the events in 1964, 1968, 1969, and 1970. The seven occurrences in the 1980s also followed the climate change.

Table 4: $\quad$ The years of abnormal climate between 1952 and 1995 [13].

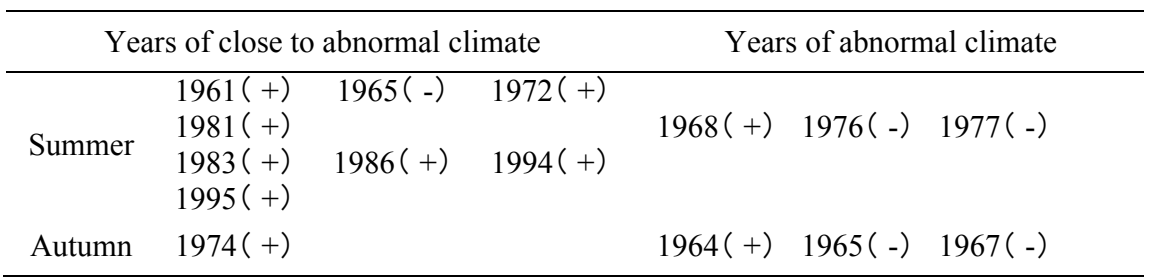

Note: (+) indicating warming; (-) indicating cooling.

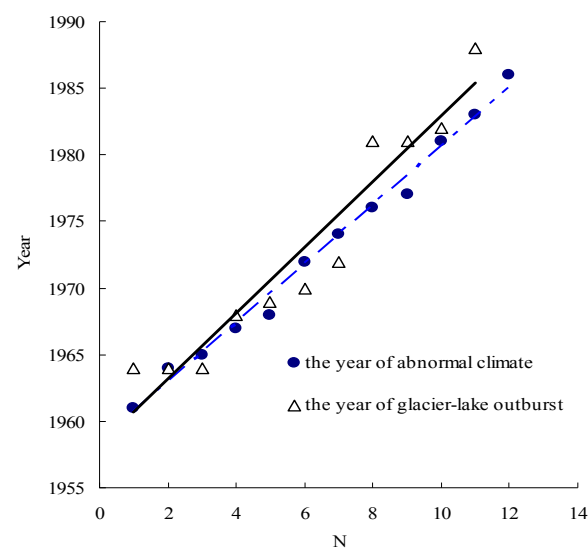

Figure 8: Correlation between the occurrences of glacier-lake break and abnormal weather. 

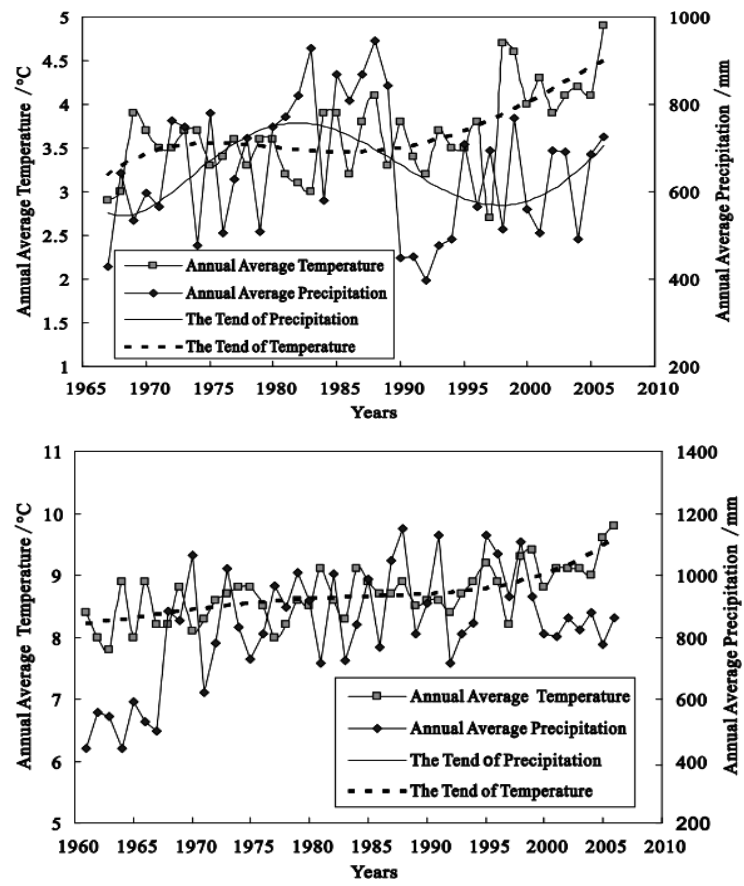

Figure 9: Annual variation of glacier lake outburst in southeast Tibet.

Comparing the abnormal years and the break events, a closed relationship appears:

Temperature abnormal year: $T=2.2168 N+1958.4\left(R^{2}=0.9902\right)$

Break events: $T=2.4727 N+1958.2\left(R^{2}=0.9239\right)$

where $N$ is the order of break event and $T$ is the corresponding year. The break line has a slope bigger than that of the temperature line, suggesting that there is a lag for the effect of temperature change. Break occurs after the climate change.

\section{Tendency of the glacial lakes}

It is expected that, compared with 1990, Tibet will have a rise of temperature of $0.8-1.2^{\circ} \mathrm{C}$ and rainfall of $7-17 \%$ by 2030 ; and the rise will be much higher by 2050. Fig.9 indicates that the temperature has been continuing to rise since 2000 . In Bomi County, the temperature reached $9.8^{\circ} \mathrm{C}$ in 2006 and the increase rate is $12.7 \%$; the rate is even as high as $33.5 \%$ in Nielamu county, where the temperature in 2006 was $4.9^{\circ} \mathrm{C}$, while the average before that year was $3.67^{\circ} \mathrm{C}$. Precipitation in these regions is rising with fluctuation. It is predicted that the runoff of the melted water will increase by $50 \%$, while the glacier area will shrink by half.

The increase of temperature and rainfall, companied with the extreme weather conditions such as rainstorms, will certainly favour breaking of glacier lakes, 
which will in turn result in debris flow because of the accompanied increase of loose material supplies in the valleys. It is concluded that debris flow due to the breaking of glacier lakes will be more active in the coming decades in southeast Tibet.

On the other hand, the glacier area will decrease with the rise of temperature. When the glacier area shrinks too much the melted water will not be enough to result in a lake break. There is a critical state of glaciers concerning the lake break. Finding the state should be an interesting study for the future.

\section{Proposal for countermeasures}

Because the debris flows induced by breaking of glacier lakes are always on a large scale, the normal countermeasures for control, such as the sediment dam and drainage groove, are highly expensive but not sufficiently powerful. So, the focus must be put on controlling the dynamical conditions that facilitate the formation of debris flow and on preventing the break of glacier lakes. Glacier lakes, particularly the end-moraine lakes, are a special kind of dammed lake that is similar to the dammed lakes of landslides and therefore can be treated with the same countermeasures $[14,15]$.

There have been various methods treating moraine lakes in the world. The simplest one is to excavate a groove to drain the water and reduce the water level. This has been widely used in treating landslide lakes, such as the dammed lakes in the Wenchuan Earthquake in 2008; and it has been also used in treating moraine lakes, such as in Peru [16]. In addition, to reduce the power of the overflow, dams can be built in the gentle section downstream from the lake.

\section{Acknowledgements}

This research is supported by the National Natural Science Foundation of China (Grant No. 40771024), Projects in the National Science \& Technology Pillar Program (2008BAKSOBO4), and the Non-profit Project of the Ministry of Water Conservancy (200801032).

\section{References}

[1] Zhu Pingyi, He Ziwen, Wang Yangcun et al. The study of typical mountain disasters in Sichuan-Tibet Highway. Chengdu: Chengdu science and technology university Press, pp.35-156, 1999

[2] Lv Ruren, Li Deji. Debris flow induced by glacier lake outburst in Tangbulang gully, Gongbujiangda, Tibet. Journal of Glaciology and Geocryology, 8(1), pp. 61-64, 1986.

[3] Xu Daoming. Characteristics of debris flow caused by outburst of glacier lake on Boqu river in Xizang. Journal of Glaciology and Geocryology, 9(1),pp.23-24, 1987 
[4] Wang Tiefeng, Liu Zhirong, Xia Chuanqing, et al. Study of glacier lakes in Nianchu river basin, Tibet. Journal of Glaciology and Geocryology, 25(suppl.2), pp.344-348, 2003.

[5] Chen Chujun, Liu Ming, Zhang Zhi. Outburst conditions of moraine dammed lakes and their flood estimation in the headwaters of Nianchu river, Tiber. Journal of Glaciology and Geocryology, 18(4), pp.347-352, 1996.

[6] Chen Xiaoqing, Chen Ningsheng, Cui Peng. Calculation of discharge of debris flow induced by glacier lake outburst. Journal of Glaciology and Geocryology, 26(3), pp.357-362. , 2004

[7] Chen Xiaoqing, Cui peng, Li Yong, et al. Changes of glacier lakes and glaciers of post-1986 in Bioqu river basin, Nyalam, Tibet. Geomorphology, 24(5), pp.298-311, 2008

[8] Cui Peng, Ma Dongtao, Chen Ningsheng, et al. the initiation, motion and mitigation of debris flow caused by glacier lake outburst. Quatermary sciences, 26(3), pp.621-628, 2003

[9] Liu Jingjing, Cheng Zunlan, Li Yong et al. Characteristics of Glacier. Lake Breaks in Tibet .Journal of catastrophology. 23(1), pp. 5460,2008

[10] Tufnell, L.: 1984, Glacier Hazards, Topics in Applied Geography, Longman, New York.

[11] Chinese Academy of Sciences - Ministry of Water Resources Chengdu Institute of Mountain Hazards and Environment, Department of the Tibet Autonomous Region Institute of Science, mud-rock flow in Tibet and the environment, Chengdu Science and Technology University Press, pp.106136,1999

[12] Wang Jiewu, Dong Guangrong .Assessment of evolution of western China Environmental (Volume I: Characteristics and evolution of the environment in western China. Beijing: Science Press, pp. 50-51, 2002

[13] Du jun. Change of temperature in Tibetan Plateau from 1961 to 2000. Acta Geographica Sinica, 56(6), pp. 682-690., 2001

[14] Ding Yihui. Assessment of environment in west China. Vol.2, Forecasting of environment changes in west China .Beijing: Science Press, pp.39, 2002.

[15] Che Tao, Jin Rui, Li Xin, et al. glacier lakes variation and potentially dangerous glacier lakes in Pumqu river basin in Tibet during of last two decades. Journal of Glaciology and Geocryology, 26(4), pp.397-402, 2004.

[16] Qing Dahe. Assessment of environmental changes in west China. Beijing: Science Press, pp.61-65, 2002 